\title{
再度罹患した小児の同側股関節部の化膿症
}

健康保険鳴門病院整形外科
西 岡 隆 夫・遠 藤 寿 男
辺 見 達 彦. 竹 川 克 一
金 沢 慶 治. 藤 井 幸 治

\section{A Case of Coxitis Purulenta in Childhood}

of

Takao Nishioka. Hisao Endo, Tatsuhiko Hemmi, Katsuichi Takekawa, Keiji Kanazawa, Kouji Fujii

Department of Orthopaedic Surgery, Health Insurance Naruto Hospital

\begin{abstract}
Pediatric coxitis is often observed in daily practice, and most cases show the coxitis simplex, whereas suppurative arthritis is rarely observed. In the past 2 years, we treated a 4-year-old girl showing coxitis purulenta on the same side two times. At the first time, suppurative arthritis of the left hip joint occurred at her age of 2 , and at the second time, suppurative myositis of the psoas occurred on the same side at the age of 4 .

The problem is the reason why the purulence occurred at the same site twice. In childhood, is there any reinfection at the region of decreased resisting power after occuqrence of coxitis purulenta once? Therefore, we would like to review the matter with reference to this case.
\end{abstract}

小児の股関節炎は日常の外来でよく遭遇する疾患で ある。その殆んどは単純性股関節炎であり，全身的な 発熱を伴うこともなく比較的短期間で治癒するもので ある。

問題は気道感染や風邪の罹患があり，その経過中に 発症した化膿性関節炎の早期発見である. 股関節痛が あり局所に腫脹や発赤や熱感があれば診断に問題はな いが，これらの所見がそしいと早期診断に難渋するこ とがある。すなわち風邪に合併した単純性股関節炎も 意外と多いものである. また本疾患の対象者が小児で あること，股関節が深い所にあり化膿症が存在しても 皮膚に反応の出現するには時間が必要なこと, 抗生物 質がすでに投与されていること，などがあり問題を複 雑にする場合がある.

今回対象とした症例は第 1 回の化膿性股関節の発症 が 2 才 6 ケ月の時であり，第 2 回も同側の腸腰筋とい う股関節周辺に化膿症を 4 才 4 ケ月の時に罹患したこ とである．問題は第 1 回の化膿性股関節炎と診断され
たのが，初診後約 3 週間を経過した後であった。さら に第 1 回目化膿性股関節炎を罹患後, 約 2 年間の無症 状期間を経過したのち, 再度同側の股関節部である腸 腰筋に化膿症を罹患したことである.

本論文の目的は，小児股関節炎なかでも上気道感染 や風邪に合併した小児股関節炎を, 単純性股関節炎か 化膿性股関節炎なるかを早期に診断する方法を知るこ とである.さらに同一股関節部に約 2 年の無症期を経て 化膿性腸腰筋炎を罹患したことに対する問題を論じる ことである。

対象および経過.（表 1)

第 1 回目股関節炎の経過. 2 才 6 ケ月女児. 左股関 節運動痛と跛行を訴え受診. 左股関節の可動域制限と 運動痛があり, 特に股内旋運動の制限が著しかった. 発熱はなかった. 股関節のレ一線所見でも異常を認め ない.

治療は消炎鎮痛剤を投与し経過を見た．第16病日左 股関節運動痛が増悪したようであった．風邪所見があ 


\section{表 1}

症例及び経過

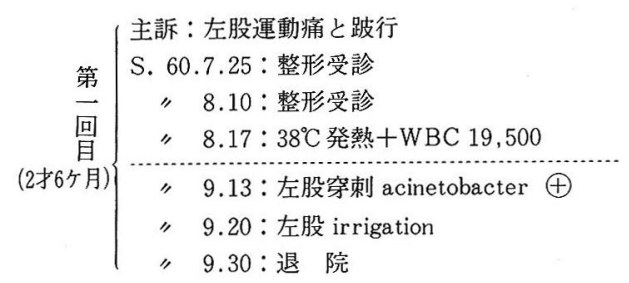

第 S. 62.7 .11 : 左股運動痛出現

宫” $7.20: 37.5^{\circ} \mathrm{C}$ 発熱+ WBC 21,600

(4才4ケ月)

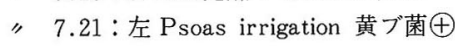

"7.30: 退 院

ク，小児科と共診の上，入院加療す．直ちに患肢の牽 引を処方す，第19病日，左股関節前面の皮䖉に腫脤を 認めるとともに圧痛が著明となり, 左化膿性股関節炎 を疑い, 化学療法を持続す。この時点になって $38^{\circ} \sim 39^{\circ} \mathrm{C}$ の発熱ありWBC 19500となる. 以後局所症状が多少 軽快するも左股関節痛持続す。第 49 病日左股関節穿刺, 化膿証明，第56日左股関節をイソジン生食にて irrigationす。の後は順調に経過，第65病日退院す。以後 約 2 年間全く左股関節痛はなく日常生活動作も正常で あった。

第 2 回目股関節炎の経過. 4 才 4 ケ月時. 左股関節 運動痛が出現, 受診す。第 9 病日, $37.5^{\circ} \mathrm{C}$ 発熱, $\mathrm{WBC}$ 21600 となる. 股関節のレー線所見は異常認めず.(図 1) 左化膿性股関節炎を疑い穿刺. 左腸腰筋膿瘍を発見. イソジン irrigation を行った, 第19病日退院, 以後問 題はない。

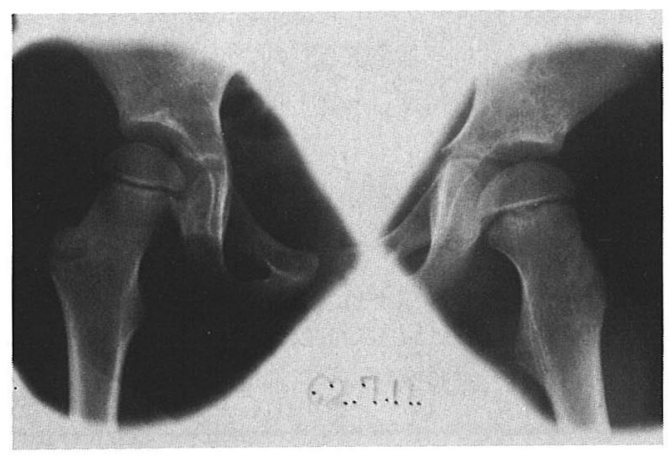

図 1 第 2 回発症時レ線

\section{考案ならびに結語}

小児股関節炎は卑近な疾患であり, その殁んどは単 純性股関節炎であり，短期間の安静で治癒することが 多い.

問題は, まず上気道感染や風邪があり, これに合併 した股関節炎を単純性か化膿性かを早期に診断する方 法の確立である. 次いで本例の如く，1側の化膿性股 関節炎の治療後の約 2 年後に同側の化膿性腸腰筋炎と いう股関節部の化膿症の発症の原因を追究することで ある.

上気道炎や風邪に合併した股関節炎を単純性か化膿 性かを早期に診断することは時として容易でないこと がある．上気道炎や風邪に股関節痛が併発すると化膿 性股関節炎の併発を念頭におくべきだが，あとで単純 性股関節炎と見られる場合が少くない. 上気道炎や風 邪があるとすでに抗生物質が投与されていることがあ る. また股関節周辺は化膿性関節症が発症しても局所 所見が小児のため確実に把握できないことがある.こ れらが問題を非常に複雑なものとしている.

現実の問題としては血液所見や持続する股関節痛や 局所の腫脹が疑われるなら，しばらく経過を見た上で， 厳重な管理のもとに股関節の穿刺が試みられてよいと 考壳る。

一側の化膿性股関節炎が治癒し，2 年経過後に発症 した同側の化膿性腸腰筋炎の罹患が，さきの化膿性股 関節炎と何等かの関係があるのであろうか. この両者 の間には時間の経過があること, 組織が別であること から，まったく関係はないとするならことは簡単であ る。

しかし小児期は化膿性骨䯣炎や化膿性関節炎や化膿 性筋炎の比較的よく見られる時期である.これらの原 因として上気道炎との関係をあげることが多い.ここ で問題としたことは前述の化膿性股関節炎と化膿性腸 腰筋が多少とも局所的に関係があるとすることができ ないものであろうか. 局所免疫などの問題となると, ことは複雑となる．諸家のお考えを賜りたくあえて問 題を提議したのである.

\section{文献}

1) 片田重彦, 他：最近の乳児化膿性股関節炎について, 臨整外, $10: 1035-1044,1975$. 
2) Obletz, B.: Acute Suppurative Arthrit s of the Hip in the Neonatal Period, J. of Bone and Joint Surg, 42-A : 23 30, 1960

3 ) 桜井 実: 化膿性関節炎, 関節外科, $3: 443-447$, 1984.

質 問福岡済生会病院 横田 清司

(1) 観血的な切開排膿は考えなかったか.

(2) 腸腰範炎に対しての穿刺の部位はどこで行ったか.

\section{解 答}

鳴門病院 辺見 達彦

(1) 切開排膿洗浄ではなく, まず穿刺排膿洗浄を行っ たのは 2 才という女性幼年患者に対する侵襲を最小限 に抑えたかったからであり，それで不十分と考えた場 合の追加処置として切開排膿洗浄は当然考えていた。

(2) 4 才時の psoas abscessに対して腸骨窩で切開せ ずに，股関節前方部で穿刺したのは同部での広沉な腫 脹が著明であった事による。 